\title{
Assessment of sea urchin spawning induction and oocyte conservation applied to ecotoxicological assays
}

\author{
Charrid Resgalla Jr. ${ }^{1 *}$, Juliana Cristina Friedrichsen' ${ }^{1}$ Rafael Camargo \\ Souza', Danielle Cristina Vieira' ', Karoliny Deucher', Marcus Adonai Castro \\ da Silva'
}

${ }^{1}$ Universidade do Vale do Itajaí, Escola do Mar, Ciência e Tecnologia (Itajaí - Santa Catarina - Brazil)

*Corresponding author: cresgalla@univali.br

\begin{abstract}
Marine toxicity tests using sea urchin embryos and larvae are characterized by physicochemical induction for the release of gametes by adult organisms and by the production of excess gamic material after induction. Evaluating the effects of mortality that inducers cause on organisms, and the improvement in oocyte maintenance techniques for subsequent use, are actions of interest in the conservation of species and the sustainable use of this type of biological model. For this study, adults of the sea urchin species Lytechinus variegatus and Echinometra lucunter were obtained from the field for inductions and tests with their gametes in the laboratory. The species $L$. variegatus was used in maintenance experiments to assess health after induction (longline outdoor and indoor tanks) and mortality rates after induction by potassium chloride (KCl) and a mixture of potassium chloride with calcium chloride $\left(\mathrm{CaCl}_{2}\right)$, and to evaluate bacterial growth as well as antibiograms of seawater resulting from induced spawning and in vitro fertilization. For the species $E$. lucunter, experiments with the same chemical inducers on mortality rates were carried out, as well as the conservation of oocytes in artificial seawater with antibiotics selected for their efficiency and toxicity for later use. Maintenance in the laboratory tanks, filled with seawater in a closed system, showed the lowest mortality rates in the group of non-induced organisms (control). The mixture of $\mathrm{KCl}$ and $\mathrm{CaCl}_{2}$ resulted in the lowest mortality rates of the adult organisms after spawning induction. The antibiotics Chloramphenicol and Gentamicin showed moderate efficiency in inhibiting bacterial growth, but with low toxicity, demonstrating the ability to maintain the integrity of sea urchin oocytes for up to 14 days under refrigeration.
\end{abstract}

Descriptors: Spawning inductors, Surviva, Artificial sea water, Toxicity assays, Sensibility.

\section{INTRODUCTION}

Ecotoxicological assays have been a widely used tool in environmental water quality studies, assisting in the monitoring of contaminated sites and the evaluation of impacts caused by chemical agents on the biota. This type of methodology is low cost, relatively simple and can be used with several species (Zagatto,

Submitted on: 22/September/2019

Approved on: 5/April/2020

Editor: Rubens M. Lopes

2019 The authors. This is an open access article distributed under the terms of the Creative Commons license.
2006). Among the most widely used marine test organisms, embryos and larvae of echinoderms can be highlighted.

Belonging to the echinoderm group, sea urchins have been used in ecotoxicological assays and cell biology studies due the ease of obtaining their gametes and the synchronism of their development (Epel et al., 2004). For the toxicity tests, these organisms have high sensitivity and provide abundant biological material (Pagano et al., 2017).

In Brazil, since 1999, the protocols of the Companhia Ambiental do Estado de São Paulo (Environmental Company of the State of São Paulo) (CETESB) have recommended the use of embryos 
of the sea urchin Lytechinus variegatus (Lamarck, 1816) for short-term chronic toxicity tests. Later, the Associação Brasileira de Normas Técnicas (Brazilian Association of Technical Standards) (NBR/ABNT, 2012) also recommended the use of two species found on the Brazilian coast: L. variegatus and Echinometra lucunter (Linnaeus, 1758). However, the removal of these organisms from their natural environment, for use in tests, has not been monitored by impact studies on natural populations, and may have led to a decrease in abundance and disturbances to the local benthic community.

In 2014, the ICMBio launched a list of fish and aquatic invertebrate species threatened with extinction (MMA Directive No. 445). That list classified the sea urchin L. variegatus as vulnerable, limiting its use in laboratory and banning it from use until studies can prove the recovery of natural populations. Despite this restriction, there have been few studies that prove the decrease of natural populations of the species in Brazil, except for the work of Ribeiro et al. (1997), which describes mass mortality of L. variegatus on the coast of the state of Rio de Janeiro, probably caused by climatic conditions. Due to this restriction, the use of $L$. variegatus in ecotoxicological tests was prohibited, prompting the alternative use of $E$. lucunter, and generating a new demand and possible damage to natural populations, given that this species is also affected by commercial exploitation (Marenzi et al., 2006).

Once in the laboratory, the organisms are stimulated to gamete release for embryo production and use in assays. Since the 1930s, saline solution for inducing the spawning of echinodermata has been used with the sea urchin Arbacia punctulata (Lamarck, 1816). In the study of Palmer (1937), it was determined that potassium chloride $(\mathrm{KCl})$ and calcium chloride $\left(\mathrm{CaCl}_{2}\right)$ are the most effective substances in inducing spawning of the organisms. Initially, it was thought that these inducing substances acted by contracting the tissue on the walls of the gonads, causing the gametes to be released from the gonopores. Later, it was discovered that excess potassium could, among other actions, stimulate the activation of oocytes, making them suitable for fertilization (Dufresne-Dubé et al., 1983, Dale and de Santis, 1981).

Once the use of $\mathrm{KCl}$ as an agent to induce spawning became practical, two issues began to arise in laboratories as a result of the use of sea urchins for marine chronic tests. However, the warning of the damage to adult organisms caused by injection of the chemical inducer came too late, and there was high loss of excess biological material (sperm, eggs and embryos), which was disposed of after use.

Studies by Luis et al. (2005) and Gago and Luís (2011) were the first to draw attention to the high mortality rates of the sea urchin Paracentrotus lividus (Lamarck, 1816) following its induction using KCl. In Brazil, a group of researchers reported by Soares and Resgalla Jr. (2016) evaluated the effect of Lidocaine Hydrochloride and Epinephrine, an anesthetic that proved to be a good spawning inducer of $L$. variegatus. However, the results were inconclusive, as this inducer apparently caused an increase in mortality rates of the organisms, suggesting that the laboratory maintenance technique for adults after induction may have influenced survival rates.

The NBR/ABNT (2012) protocol recommends the use of spawning from at least 3 female and 3 male specimens, to ensure genetic variability in the assays, this requirement associated with a sex differentiation problem of organisms (Abessa et al., 2001), encourages the production of excess biological material. Additionally, problems of seasonality in the maturation of the gonads, which limit the collection of field organisms (Mariante et al., 2009), led to the improvement of conservation techniques of gametes in the laboratory, with greater potential to reduce the impact of removing adults from the environment. This also serves as a conservation strategy of the species, based on better use of biological material obtained in the laboratory (Malgarin and Resgalla Jr., 2015; Ribeiro et al., 2018a, 2018b).

Oocyte cryopreservation techniques are not as successful as has been observed for sperm. However, Malgarin and Resgalla Jr. (2015), using the technique of Epel et al. (2004), managed to maintain the integrity of the female gamete for 18 days in artificial seawater with Chloramphenicol at $15^{\circ} \mathrm{C}$. Despite these results, there are still issues to be investigated in this technique, such as the use of different antibiotics and the evaluation of their toxicity to the preserved embryos.

This work seeks to determine the best way to maintain sea urchins after spawning, in the search for an efficient induction technique that will guarantee a supply of gametes and reduce mortality of adult specimens, and to investigate improvements in the conservation of gametes for laboratory use. Due to 
the limitations imposed by ICMBio Directive MMA No. 445 , some of the tests were initially performed with the species $L$. variegatus and some with E. lucunter, in an attempt to comply with the classification of organisms for their use in laboratory assays. In any case, and based on previous work (Malgarin and Resgalla Jr., 2015; Soares and Resgalla Jr., 2016), the results presented here could be considered comparable for the vast majority of sea urchins that are commonly found on the Brazilian coast.

\section{MATERIALS AND METHODS}

\section{Obtaining ORganisms AND the eXPeRIMENTS}

Sea urchins of the species L. variegatus and $E$. lucunter were collected by autonomous scuba divers at Feia Island, on the north coast of the state of Santa Catarina (26 $44^{\prime} 41.09^{\prime \prime} \mathrm{S}$ and $\left.48^{\circ} 38^{\prime} 13.62^{\prime \prime} \mathrm{W}\right)$, in different periods, during the period 2012 to 2018 (2012-2014 maintenance assays of $L$. variegatus; 2013-2014 assays with antibiotics in L. variegatus; 2013-2014 assays of induction with $\mathrm{CaCl}_{2}$ with $L$. variegatus; and 2015-2018 assays of induction with $\mathrm{CaCl}_{2}$ with $E$. lucunter and oocyte maintenance assays). All the sample collections were carried after obtaining Authorization for Activities for Scientific Purposes, issued by ICMBio, through the Biodiversity Authorization and Information System - SISBIO (49568-2, 54336-1 and 68747-1). The samples were collected by the staff of the Laboratorio de Mergulho Submarino UNIVALI (UNIVALI's Submarine Diving Laboratory) and then transported in coolers, without aeration, to the EMCT/UNIVALI Ecotoxicology Laboratory, where they were kept in a 400-liter tank with seawater at $30 \pm 2$ salinity, temperature of $23^{\circ}$ $\pm 2^{\circ} \mathrm{C}$, equipped with particulate and UV filters and dissolution filters, in a closed circulation system, before being used in the experiments. The tanks were cleaned once a week by suctioning the bottom debris and renewing $20 \%$ of the total seawater volume. The non-induced organisms, or those that survived the assays, were returned to their environment of origin.

\section{Assays FOR TESTING THE MAINTENANCE SYSTEM}

For the assays to assess the survival rate of $L$. variegatus in different maintenance systems, four experiments were performed from 2012 to 2014, to verify the maintenance of adult organisms in perforated monoblock boxes (62 liters or $0.94 \mathrm{~m}^{2}$ ), using the long-line system in the field and in the Armação do Itapocorói bay. There was a maximum density of 10 organisms per box, and 68 organisms were used. A second maintenance system involved 8 experiments in 400-liter internal tanks subdivided into fractions of 133 liters or $1.4 \mathrm{~m}^{2}$, at a maximum density of 10 organisms per subdivision, with a total of 112 organisms used. The water treatment system was the same as previously presented for the laboratory maintenance tanks. In both types of maintenance system, the organisms were fed with Sargassum sp, Ulva sp and Hypnea sp obtained in the Armação inlet, and offered in abundance every 3 days. Comparisons between treatments were carried out using unifactorial variance analysis (ANOVA), considering all maintenance experiments carried out at different times of the year with 4 experiments in field long-line and 8 in laboratory tanks.

Having determined the best maintenance system for adult organisms, experiments were carried out on different spawning induction techniques and their effects on mortality rates in the period 2013/2014 for $L$. variegatus and in the period 2015/2018 for $E$. lucunter. For L. variegatus, different spawning inducers were used: injection of $2 \mathrm{~mL} \mathrm{KCl} 0.5 \mathrm{M}$ into the coelomic cavity (according to NBR/ABNT, 2012) in 11 experiments, using a total of 129 organisms; $2 \mathrm{~mL}$ injection of $\mathrm{KCl} 0.5 \mathrm{M}$ and $\mathrm{CaCl}_{2} 0.25 \mathrm{M}$ mixture at a 1:1 ratio into the coelomic cavity (Palmer, 1937) in 4 experiments, using a total of 46 organisms; $1 \mathrm{~mL}$ injection of Lidocaine Hydrochloride and Epinephrine into the coelomic cavity (Soares and Resgalla Jr., 2016) in 2 experiments, using a total of 24 organisms; and only one $30 \mathrm{~V}$ electric shock into the aboral region (gonopore region) (NBR/ABNT, 2012), using 12 organisms. For $E$. lucunter, $\mathrm{KCl}$ induction and $\mathrm{KCl}$ and $\mathrm{CaCl}_{2}$ mixture were performed only in 5 experiments, using a total of 150 organisms. For both species, mortality rates were observed after maintenance of the organisms in the previously described 400 -liter tanks. Due to the high mortality, rates observed using lidocaine induction and electric shock, these treatments were abandoned for $L$. variegatus and were not tested for $E$. lucunter. Maintenance times were reduced from 15 to 5 days for E. lucunter, as there were no significant differences compared to these times for the use of $\mathrm{KCl}$ and $\mathrm{KCl} \& \mathrm{CaCl}_{2}$ mixture in $L$. variegatus assays. 
Comparisons between mortality rates were performed by one-way analysis of variance (ANOVA) considering all experiments carried out at different times of the year and for each species separately. Due to the number of experiments carried out, and for the purpose of comparison between species, only the control (without induction), $\mathrm{KCl}$ induction and $\mathrm{KCl}$ and $\mathrm{CaCl}_{2}$ treatments were compared.

\section{EFFICIENCY AND TOXICITY OF ANTIBIOTICS}

The biological material (sperm, eggs or embryos) obtained from the inductions carried out up to 2014 for the L. variegatus were used for the evaluation of growth of bacterial colonies, the antibiotic susceptibility tests, and the embryo-larval toxicity assays of some antibiotics of interest. The biological material obtained from E. lucunter in 2018 was used for the conservation and viability tests of eggs in antibiotic medium.

The seawater from the collection of eggs of $L$. variegatus in the process of induction and fecundation was used for bacterial isolation and culture. The culture medium used for growth and isolation of marine bacterial strains was 2216E Marine Agar. The samples were incubated at $37^{\circ} \mathrm{C}$ for 48 hours. After growth, colonies were isolated and maintained in the same medium for antibiogram testing. For sensitivity testing, the disk-diffusion method proposed by Kirby-Bauer and recommended by the National Committee for Clinical Laboratory Standards (NCCLS, 2003) was used. The colonies were tested against 17 antibiotics, and those selected for the toxicity assays were Polymyxin B, Nalidixic acid, Chloramphenicol, Gentamicin and Tetracycline, due to their efficiency in controlling bacterial growth and their availability.

The previously listed antibiotics were used in embryo-larval assays of $L$. variegatus to assess their toxicity. The assays were performed according to the norms established by the NBR/ABNT (2012), with 24 hours exposure of embryos to antibiotics in four replicates, for greater control. These assays were carried out in clear $15 \mathrm{~mL}$ vials containing $10 \mathrm{~mL}$ of test solution with approximately 300 embryos at $24^{\circ} \mathrm{C} \pm 1{ }^{\circ} \mathrm{C}$, photoperiod 12:12 D: $\mathrm{N}$. The assays were terminated by adding $1 \mathrm{~mL}$ of $4 \%$ formaldehyde solution to each vial. The physicochemical parameters monitored from the beginning to the end of the experiment were $\mathrm{pH}$, salinity and dissolved oxygen. Subsequently, under a microscope, using a Sedgewick rafter chamber, the percentage of abnormally developed larvae was observed to estimate $\mathrm{EC}_{50}$ (Median Effective Concentration).

\section{Oocyte StORAge Medium}

For the oocyte conservation for use in subsequent experiments, only experiments with the species E. lucunter were carried out after 2015. These were based on the results obtained from the studies with antibiotics in the experiments with the $L$. variegatus presented in this work and on the studies by Malgarin and Resgalla Jr. (2015). The biological material used came from the inductions performed in the assays with inducing agents.

Initially, for the viability test of the maintained oocytes, sperms were stored in Eppendorf ${ }^{\circledR}$ tubes, under refrigeration, without dilution with seawater and in the dark. Under these conditions, sperm can be viable for up to 7 days. For the oocyte maintenance assays, four different media were tested; (1) the control, carried out using filtered natural seawater $(0.5 \mu \mathrm{m})$, sterilized by UV and by heating, (2) reconstituted calcium- and magnesium-free seawater $\left(31 \mathrm{~g}\right.$ of $\mathrm{NaCl}, 0.8 \mathrm{~g}$ of $\mathrm{KCl}, 0.2 \mathrm{~g} \mathrm{NaHCO}_{3^{\prime}} 1.6 \mathrm{~g}$ of $\mathrm{Na}_{2} \mathrm{SO}_{4^{\prime}}$ which were diluted in for $1 \mathrm{~L}$ of distilled water) according to Malgarin and Resgalla Jr. (2015), (3) reconstituted calcium- and magnesium-free sea water with Chloramphenicol (25 $\mathrm{mg} \mathrm{L}^{-1}$ ) and (4) reconstituted calcium- and magnesium-free sea water with Gentamicin (100 $\left.\mathrm{mg} \mathrm{L}^{-1}\right)$. Antibiotic concentrations were established based on the results of the toxicity assays.

After obtaining the oocytes, these were carefully washed at least 3 times with the media solutions in which they would be maintained, in order to eliminate dirt particles and minimize contamination. After washing, three $5 \mathrm{~mL}$ aliquots were taken from each sample for analysis of cell integrity under a microscope.

The material was transferred to $200 \mathrm{~mL}$ cell culture vials, each containing different media. These culture vials were kept horizontally in an incubator at $15^{\circ} \mathrm{C}$, without light. The culture medium was renewed every 48 hours, allowing the cells to decant, removing $80 \%$ of the supernatant volume and replacing it with a renewed medium in the same concentration. With each renewal, aliquots containing oocytes were taken for 
assessment of cell integrity by morphological analysis under an optical microscope with 200-fold magnification. The viability of the maintained oocytes was tested for fecundation capability using $250 \mu \mathrm{L}$ of oocyte solution added to a vial containing $10 \mathrm{~mL}$ of natural seawater and 1 drop of refrigerated sperm solution after activation $(0.5 \mathrm{~mL}$ of sperm with $24 \mathrm{~mL}$ of natural seawater). After 2 hours, the test vials were fixed with the addition of $0.5 \mathrm{~mL}$ of $4 \%$ formaldehyde solution, and the presence of embryos with cell divisions was observed under an optical microscope. This procedure was similar to the fertilization test presented by USEPA (2002).

\section{RESULTS}

\section{MORTALITY}

Maintenance techniques tested for the species $L$. variegatus indicated a higher survival rate (or lower mortality rate) of adult organisms under the controlled conditions of the laboratory tank (Figure 1). There was a trend of higher mortality rates in the field, even within just a few days of maintenance. Due to the high variability in mortality rates observed, significant differences were observed only in 15 days of maintenance. Under field conditions (long-line), the maintenance of adult sea urchins is subject to stormy conditions, as well as higher ripple, which create a stressful environment in the boxes, as well as problems with decreased water circulation caused by increased biofouling, and competition and predation of invasive fauna in the boxes.

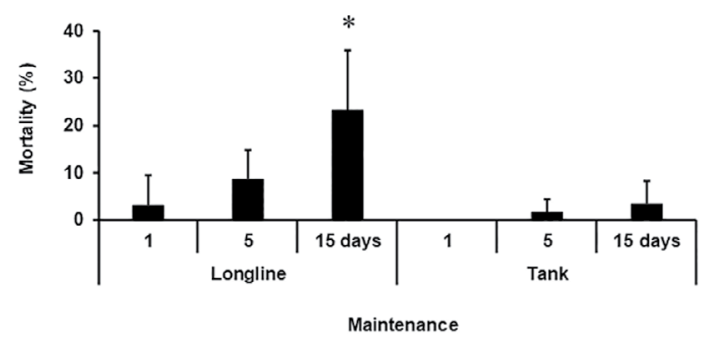

Figure 1. Average percentage and standard deviation of mortality for the $L$. variegatus at 1, 5 and 15 days in field long-line structures (perforated monoblock boxes), and in a laboratory tank. Longline - 4 experiments carried out in different periods, totaling 68 organisms; and Tank - 8 experiments carried out in different periods, totaling 112 organisms. *Significant difference $[F=11.035$ $(2.53,0.05,5,30)]$.
Having defined the best system for maintenance of adult organisms, the effect of spawning induction systems on mortality rates of the species $L$. variegatus was tested. It is noteworthy that a 30 Volt electric shock resulted in visible damage to the surface of the organisms, discouraging the repeated use of this method. Similarly, injection of Lidocaine with Epinephrine resulted in high mortality rates (up to $67 \%$ ), and this method was also abandoned. Due to all the above, these two techniques were not used in many repetitions and were not considered in the analyses of the comparisons.

The comparison assays were focused on control (non-induced organisms), induction using the mixture of $\mathrm{KCl}$ and $\mathrm{CaCl}_{2}$, and induction with $\mathrm{KCl}$ alone. The mortality rates recorded using the different methods indicated higher percentages when using $\mathrm{KCl}$ induction, reaching up to $67 \%$ mortality, while the $\mathrm{KCl}$ and $\mathrm{CaCl}_{2}$ mixture presented lower percentages (up to 20\%) (Figure 2).

The success rates of induction for both $\mathrm{KCl}$ and $\mathrm{KCl}$ and $\mathrm{CaCl}_{2}$ were higher than $60 \%$ of the induced organisms, with fertilization percentages above $80 \%$ of the eggs and sperms obtained. Also, the success rates did not show any marked efficiency for any particular sex, the variability being associated with the seasonal behavior of the species.

Similar results were also obtained for the inductions carried out for E. lucunter using the $\mathrm{KCl}$ and $\mathrm{CaCl}_{2}$ mixture and $\mathrm{KCl}$ only (Figure 3). Despite the high variability of results and the lack of significant differences between methods, the same trend was observed, with lower mortality rates for organisms induced using $\mathrm{KCl}$ and $\mathrm{CaCl}_{2}$.

E. lucunter showed similar behavior to L. variegatus in terms of induction efficiency ( $>60 \%$ of organisms responded to inducers) and no efficiency trends for sex. Fertilization percentages were also above $80 \%$.

Additional tests using only the $\mathrm{CaCl}_{2} 0.25 \mathrm{M}$ as inducing agent and involving 29 organisms of $E$. lucunter presented low efficiency in stimulating spawning, with a success rate of $34.5 \%$, lower than the minimum of $60 \%$ observed for $\mathrm{KCl}$ and $\mathrm{KCl} \& \mathrm{CaCl}_{2}$. However, these tests presented low mortality rates when compared to the $\mathrm{KCl}$ alone, and similar rates to those of the mixture $\mathrm{KCl}$ and $\mathrm{CaCl}_{2}$. 


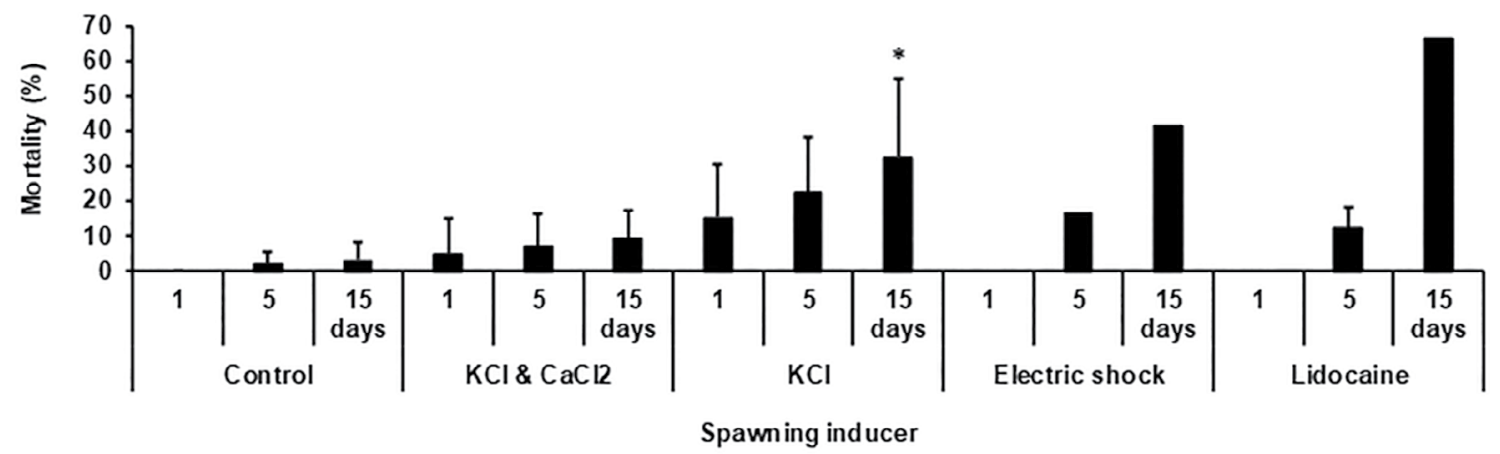

Figure 2. Average percentage and standard deviation of mortality for the L. variegatus at 1,5 and 15 days in the laboratory tank after induction of spawning by $\mathrm{KCl} 0.5 \mathrm{M}$ and $\mathrm{CaCl}_{2} 0.25 \mathrm{M}$ injection (1:1); $\mathrm{KCl} 0.5 \mathrm{M}$ injection, electric shock, $2 \mathrm{~mL}$ Lidocaine with epinephrine injection and control group (without induction). $\mathrm{KCl}$ and $\mathrm{CaCl}_{2}-4$ experiments with a total of 46 organisms; $\mathrm{KCl}-11$ experiments with a total of 129 organisms; Electric shock - one experiment with 12 organisms, and Lidocaine - 2 experiments with a total of 24 organisms. *Significant difference of the $\mathrm{KCl}$ 15 days to $\mathrm{KCl}$ and $\mathrm{CaCl}_{2}$ and Controls at 5 and 15 days $[\mathrm{F}=5.468(2.53,0.05,5,30)]$.

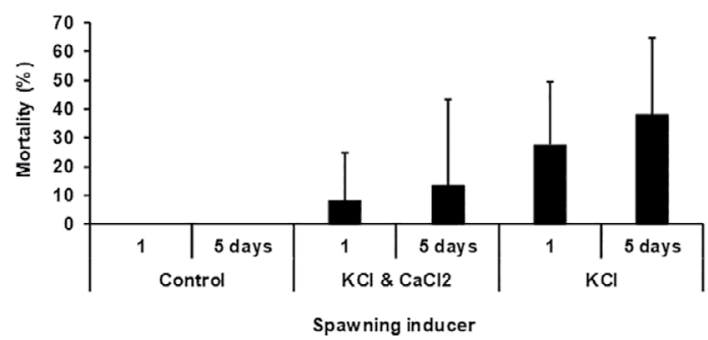

Figure 3. Average percentage and standard deviation of mortality for $E$. lucunter at 1 and 5 days in the laboratory tank after induction of spawning with $\mathrm{KCl} 0.5 \mathrm{M}$ and $\mathrm{CaCl}_{2} 0.25 \mathrm{M}(1: 1)$ injection; $\mathrm{KCl}$ $0.5 \mathrm{M}$ and control group (without induction). All treatments were repeated in 5 experiments with 10 organisms each. No significant differences between treatments were found $[F=1.345(3.34,0.05$, $3,14)]$.

\section{Oocyte conservation}

A total of 21 bacterial colonies isolated from the seawater of egg collection were obtained after induction of adult sea urchins and the fecundation process. Next, the antibiogram tests were carried out with antibiotic discs, and 17 different antibiotics were tested. Of the antibiotics tested, the most efficient ones in controlling bacterial growth, in order of efficiency, were: Imipenem (12 sensitive colonies out of 17 tested); Polymyxin-B (11/16); Nalidixic Acid (10/15); Chloramphenicol (7/21); Cephatoxim (1/3); Gentamycin (5/21) and Streptomycin (2/13). The other antibiotics did not present sensitivity percentages in the colonies tested (Table 1).

Toxicity tests performed with the major antibiotics showed that the toxicity of the antibiotics generally followed their efficiency in controlling bacterial growth. Polymyxin-B and Nalidixic Acid were the most efficient in controlling bacterial growth, and the most toxic for the embryo-larval assay, while Gentamicin was the least toxic of the antibiotics (Table 1). Despite this relationship between toxicity and efficiency in controlling bacterial growth, the antibiotic Tetracycline showed high toxicity and low efficiency in bacterial control. The other antibiotics were not tested due to their unavailability, or to optimize the work, with antibiotics being chosen for their efficiency in controlling bacterial growth.

Having determined the efficiency and toxicity of the antibiotics, Chloramphenicol and Gentamicin were used for the conservation of refrigerated oocytes of E. lucunter. Two experiments were carried out and within 4 days, the sterile natural seawater control cells already had a high percentage of broken and unviable oocytes (Table 2). The second method that caused their cells to become disintegrated was the water control using calcium and magnesium-free artificial seawater and without antibiotics for 5 days.

Treatment with $25 \mathrm{mg} \mathrm{L}^{-1}$ Chloramphenicol presented intact oocytes (50-70\%) until day 18 , while treatment with $100 \mathrm{mg} \mathrm{L}^{-1}$ Gentamicin was less efficient, maintaining oocyte integrity ( $>70 \%$ ) for up to 14 days.

After the first 48 hours of maintenance, cells were subjected to the fertilization assay to assess the viability of the preserved oocytes. In this assay, it was observed that cells from both controls were fertilized, and it was possible to observe the presence of the 
Table 1. Antibiotic efficiency (\%, number of colonies inhibited over total colonies tested) of bacterial growth inhibition and toxicity to embryo-larval sea urchins of the antibiotics tested (EC50 - Median Effective Concentration and C195\% 95\% Confidence Interval).

\begin{tabular}{|c|c|c|c|}
\hline \multirow{2}{*}{ Antibiotic } & \multirow{2}{*}{ Efficiency (\%) } & \multicolumn{2}{|c|}{ Toxicity } \\
\hline & & $\mathrm{EC}_{50}\left(\mathrm{mg} \mathrm{L}^{-1}\right)$ & $\mathrm{Cl} 95 \%$ \\
\hline Imipenem & 70.59 & - & - \\
\hline Polymyxin-B & 68.75 & 23.67 & 1.38 \\
\hline Nalidixic Acid & 66.67 & 23.73 & 1.58 \\
\hline Chloramphenicol & 33.33 & 44.54 & 5.52 \\
\hline Cephatoxim & 33.33 & - & - \\
\hline Gentamicin & 23.81 & 206.3 & 19.43 \\
\hline Streptomycin & 15.38 & - & - \\
\hline Tetracycline & 0.00 & 26.79 & 1.82 \\
\hline Penicillin G & 0.00 & - & - \\
\hline Vancomycin & 0.00 & - & - \\
\hline Piperacycline/Tozobactam & 0.00 & - & - \\
\hline Kan - Kanamycin & 0.00 & - & - \\
\hline Cefotaxime & 0.00 & - & - \\
\hline Tobramycin & 0.00 & - & - \\
\hline Rifampicin & 0.00 & - & - \\
\hline Erythromycin & 0.00 & - & - \\
\hline Nitrofurantoin & 0.00 & - & - \\
\hline
\end{tabular}

Table 2. Percentage of intact E. lucunter oocytes per day of storage in different culture media.

\begin{tabular}{|c|c|c|c|c|c|c|c|c|c|}
\hline \multirow{2}{*}{ Treatment } & \multicolumn{9}{|c|}{ Days of storage } \\
\hline & 1 & 2 & 3 & 4 & 5 & 7 & 14 & 18 & 20 \\
\hline \multicolumn{10}{|c|}{ Sterile natural seawater } \\
\hline \multicolumn{10}{|l|}{ Artificial seawater } \\
\hline \multicolumn{10}{|c|}{ Artificial seawater + Gentamicin } \\
\hline \multicolumn{10}{|c|}{ Artificial seawater + Chloramphenicol } \\
\hline Percentage scale & \multicolumn{3}{|c|}{$>70 \%$} & & \multicolumn{2}{|c|}{$50-70 \%$} & & \multicolumn{2}{|c|}{$0 \%$} \\
\hline
\end{tabular}

fertilization membrane, but they were damaged in the first cell division of the embryonic development. The oocytes conserved with both antibiotics showed development above $80 \%$ with embryos in the stage of 2 to 4 cells.

\section{DISCUSSION}

This study highlights the importance of investigating new less aggressive methods of inducing spawning in sea urchins in order to minimize stress to animals, reduce their mortality and ensure spawning quality. It is also necessary to make the best use of the gametic material collected, through techniques capable of prolonging the viability of the gametes, especially oocytes.

The data obtained confirm that injection of $\mathrm{KCl}$ solution is still one of the most effective solutions for obtaining gametes from different species of sea urchin. However, this substance has high toxicity, causing lethality to most organisms used in this study, indicating the need for control in the administration of a less aggressive dosage and concentration.

In experiments carried out with the sea urchin $P$. lividus, Gago and Luís (2011) point out that the higher the $\mathrm{KCl}$ concentration injected, the higher the spawning volume obtained, but, therefore, the higher the 
adult mortality rates. The same was observed by Soares and Resgalla Jr. (2016), who showed that even with optimal release rates of gamic material, they obtained mortality rates of $10 \%$ to $30 \%$ with the $\mathrm{KCl}$ inducer and up to $40 \%$ with the inducer Lidocaine + Epinephrine, finding a relationship between spawning and mortality rates. This work also confirms the results obtained by Soares and Resgalla Jr. (2016), who found that maintenance in tanks is adequate for evaluation of organisms after spawning.

The combination of $\mathrm{KCl}$ and $\mathrm{CaCl}_{2}$ proved to be equally capable of inducing spawning of sea urchins of different species, not interfering with the $\mathrm{KCl}$ activity alone. However, it has the advantage that it causes less damage to adult organisms, which may be due to a reduction in the concentration of the $\mathrm{KCl}$ dose administered (1:1 ratio of $\mathrm{KCl}$ and $\mathrm{CaCl}_{2}$ solutions) or to the action of $\mathrm{CaCl}_{2}$ as an antidote to $\mathrm{KCl}$.

In humans, calcium chloride is a substance widely used in the treatment of patients with hyperkalemia, a clinical condition in which there is an imbalance of blood ions, causing an increase in the concentration of potassium. In addition to fainting, this condition can cause decreased heartbeat and muscle paralysis. One way to revert hyperkalemia is by injecting $\mathrm{CaCl}_{2} 10 \%$. Calcium works as an antidote to $\mathrm{KCl}$ and enables the formation of antagonists, reducing its toxic effects on the myocardium and normalizing heart rate (Évora et al., 1999; Battefort et al., 2012; Vieira Neto and Moyses Neto, 2003). Despite the large differences between the systems of humans and sea urchins, both have various processes that require the presence of calcium (Leite and Marques-Santos, 2012) and, therefore, its antagonistic substance should work in a similar way. In experiments with sea urchins using $\mathrm{CaCl}_{2}$ injection after $\mathrm{KCl}$ induction (data not shown), the results also showed higher adult survival rates; however, this method was abandoned, as it subjected the organisms to additional stress by repeated injections in the process of obtaining gametes.

Seawater has a $5 \%$ concentration of calcium (Kato, 1966). This means there is an ionic difference between the intracellular medium and the environment, indicating, in turn, that high concentrations of calcium generate an imbalance of ions between the intra- and extracellular environment, and causing the external calcium to migrate into the interior of cells through the channels, and consequently activate oocytes
(Vacquier, 2011). Also, for this reason, we opted for the use of calcium- and magnesium-free reconstituted water in the formulation of oocyte conservation media, maintaining its inactivity under refrigeration. In addition, Leite and Marques-Santos (2012) investigated the influence of extracellular calcium on the fertilization and embryo development of E. lucunter, and observed that for embryos in which the eggs or sperm had been collected in a medium containing calcium, fertilization was $100 \%$, while in the gametes collected in seawater free of calcium, this fertilization rate was reduced by around $6 \%$.

Sea urchin sperm are resistant cells, capable of being frozen, as proven by Malgarin and Resgalla Jr. (2015). However, there is still no record of an efficient freezing technique for sea urchin oocytes due to the high sensitivity of this cell type. Alternatively, both male and female gametes can be stored easily under refrigeration for two weeks (Spiegler and Oppenheimer, 1995), but the oocytes need to be stored in a solution containing antibiotics. This is because it is a biological material, where cells are in aqueous medium where they can become contaminated by microorganisms and subject to deterioration.

Epel et al. (2004), using a mixture of antibiotics, was able to store oocytes of two species of sea urchins under refrigeration for a period of up to three weeks. Malgarin and Resgalla Jr. (2015) were also successful in storing oocytes of $L$. variegatus for up to 20 days using the antibiotic Chloramphenicol.

According to Epel et al. (2004), oocyte death outside the ovary only occurs because there is bacterial contamination after spawning, but under the right conditions, they can be stored for more than a week. However, antibiotics should be chosen with caution, as many of them may have a toxic effect on cells, depending on their composition and dosage, causing gametes to die.

Both Chloramphenicol and Gentamicin are antibiotics that act by blocking the protein synthesis of bacteria; however, Gentamicin also causes changes in the membrane due to the entrance of aminoglycosides in the bacterial cells (Haraguchi, 2000). In Brazil, these antibiotics are widely used in hospitals, and often end up being eliminated with hospital waste. A study by Berto et al. (2009) showed that of the 133 strains of bacteria isolated from hospital effluent, $76 \%$ of the Streptococcaceae bacteria were resistant 
to Chloramphenicol, while $68 \%$ of the bacteria in this same group were sensitive to Gentamicin treatment. This is a negative aspect of the technique, as with the use and generation of waste, there is a tendency to stimulate the resistance of bacterial fauna, prompting the search for other antibiotics for use in the future.

Costa et al. (2008) tested the antimicrobial action of some drugs on infection-causing bacteria in fish of the species Rhamdia quelen in order to trace the sensitivity profile of these bacteria. In that study, 51 bacterial isolates from different families were obtained. Of these, $100 \%$ of the isolates were sensitive to Gentamycin, and more than $90 \%$ were sensitive to Chloramphenicol. This demonstrates the great potential of these two drugs in controlling microbial growth in aquatic environments. In this study, it was observed that there is a relationship between the antibiotic efficiency and its toxicity, and of the 17 antibiotics tested to control bacterial growth in seawater, the most efficient ones also proved to be the most toxic to sea urchin oocytes. From this antibiogram test, Chloramphenicol and Gentamycin presented an average bacterial control spectrum.

Finally, studies are still needed to assess whether the use of gametes maintained with antibiotics can interfere with the sensitivity of these test organisms in toxicity tests. This would allow a correct assessment of toxicity in copulation with the gametes recently obtained from adult organisms.

\section{CONCLUSION}

$\mathrm{KCl}$ proved to be a good inducer of gamete spawning of sea urchins from the species $L$. variegatus and Echinometra lucunter, but it influences the survival of the organisms, causing high mortality rates. In turn, $\mathrm{CaCl}_{2}$ was found to be a substance that works as an antidote to $\mathrm{KCl}$ induced mortality, and may present a synergism for gamete induction, presenting benefits when injected together with $\mathrm{KCl}$. The $\mathrm{KCl}$ and $\mathrm{CaCl}_{2}$ mixture is highly recommended for obtaining sea urchin gametes. However, $\mathrm{CaCl}_{2}$ cannot be used as an inducer alone, as the substance has a lower induction capacity.

Regarding the conservation of the oocytes from the sea urchin Echinometra lucunter, the antibiotics Chloramphenicol (25 $\mathrm{mg} \mathrm{L}^{-1}$ ) and Gentamicin (100mg $\mathrm{L}^{-1}$ ) proved to be efficient in bacterial control, allowing the biological material to remain viable, under refrigeration, for more than 14 days.

\section{ACKNOWLEDGEMENTS}

The authors thank the Superintendence of the Port of Itajaí for its financial support, through the Monitoring Program of the Port Region of the ItajaíAçu River.

\section{AUTHOR CONTRIBUTIONS}

C. R. Jr. - Writing - original draft; Writing - review \& editing.

J. C. F. - Formal analysis; Investigation; Methodology.

R.C.S. - Formal analysis; Investigation; Methodology.

D.C.V. - Formal analysis; Investigation; Methodology.

K. N. D. - Formal analysis; Investigation; Methodology.

M. A.C. S. - Formal Analysis; Methodology; Writing review \& editing.

\section{REFERENCES}

ABESSA, D. M. S., RACHID, B. R. F. \& SOUSA, E. C. P. M. 2001. Preliminary results in the sexual dimorphism determination of the sea urchin Lytechinus variegatus (Lamarck, 1816), Echinoidea, Toxopneustidae. Brazilian Journal Oceanography, 49, 1-2, 133-135.

NBR/ABNT. Associação Brasileira de Normas Técnicas. 2012. ABNT-NBR 15350, Ecotoxicologia aquática - Toxicidade crônica de curta duração - Método de ensaio com ouriço-do-mar (Echinodermata: Echinoidea), ABNT, Brasil.

BATTEFORT, F., DEHOURS, E., VALLÉ, B., HAMDAOUI, A., BOUNES, V. \& DUCASSÉ, J. L. 2012. Suicide attempt by intravenous potassium self-poisoning: a case report. Case Reports in Emergency Medicine, 2012, 323818, DOI: http://dx.doi. org/10.1155/2012/323818.

BERTO, J., ROCHENBACH, G. C., BARREIROS, M. A., CORRÊA, A. X. R., PELUSO-SILVA, S. \& RADETSKI, C. M. 2009. Physico-chemical, microbiological and ecotoxicological evaluation of a septic tank/Fenton reaction combination for the treatment of hospital wastewaters. Ecotoxicology and Environmental Safety, 72, 1076-1081.

COSTA, M. M., PEIXOTO, R. M., BOIJINK, C. L., CASTAGNA, L., MEURER, F. \& VARGAS, A. C. 2008. Sensibilidade antimicrobiana de bactérias isoladas de Jundiá (Rhamdia quelen). Pesquisa Veterinária Brasileira, 28, 10, 477-480.

DALE, B. \& de SANTIS, A. 1981. Maturation and fertilization of the sea urchin oocyte: an electrophysiological study. Developmental Biology, 85, 2, 474-484.

DUFRESNE-DUBÉ, L., DUBÉ, F., GUERRIER, P. \& COUILLARD, P. 1983. Absence of a complete block to polyspermy after fertilization of Mytilus galloprovincialis (Mollusca, Pelecypoda) oocytes. Developmental Biology, 97, 1, 27-33.

EPEL, D., VACQUIER, V. D., PEELER, M., MILLER, P. \& PATTON, C. 2004. Sea urchin gametes in the teaching laboratory: good experiments and good experiences. In: ETTENSOHN, C., 
WRAY, G. A. \& WESSEL, G. M. (eds.), Development of sea urchins, ascidians, and other invertebrate. Deuterostomes: experimental approaches. Methods in cell biology, v. 74, pp. 798-824.

ÉVORA, P. R. B., REIS, C. L., FEREZ, M. A., CONTE, D. A. \& GARCIA, L. V. 1999. Distúrbios do equilíbrio hidroeletrolítico e do equilíbrio acidobásico - uma revisão prática. Medicina Ribeirão Preto, 32, 4, 451-469.

GAGO, J. \& LUÍS, O. J. 2011. Comparison of spawning induction techniques on Paracentrotus lividus (Echinodermata: Equinoidea) broodstock. Aquaculture International, 19, 1, 181191.

HARAGUCHI, T. 2000. Antibióticos: classificação geral. Revista Brasileira de Medicina, 57, 10, 1109-1128.

KATO, K. 1966. Studies on calcium content in seawater: I. Chelatometric determination of calcium in seawater. Boletim do Instituto Oceanográfico, 15, 1, 25-28.

LEITE, J. C. A. \& MARQUES-SANTOS, L. F. 2012. Extracellular Ca2+ influx is crucial for the early embryonic development of the sea urchin Echinometra lucunter. Journal of Experimental Zoology. Part B, Molecular and Developmental Evolution, 318, 2, 123-133.

LUIS, O., DELGADO, F. \& GAGO. J. 2005. Year-round captive spawning performance of the sea urchin Paracentrotus lividus: relevance for the use of its larvae as live feed. Aquatic Living Resources, 18, 1, 45-54.

MALGARIN, J. \& RESGALLA, C. JR. 2015. Extending the viability of spermatozoa and eggs of the sea urchin Lytechinus variegatus. CryoLetters, 36, 3, 174-181.

MARENZI, A. W. C, TAMAKI, N. T. \& MANZONI, G. C. 2006. Biological and economic subsidies for rational exploration of the sea-urchin Echinometra lucunter (L., 1758), Proceedings of the $8^{\text {th }}$ International Coastal Symposium, Journal of Coastal Research, SI 39, Itajaí, SC, Brazil, pp. 1299-1301.

MARIANTE, F. L. F., LEMOS, G. B., EUTRÓPIO, F. J. \& GOMES, L. C. 2009. Biologia reprodutiva de Echinometra lucunter (Echinodermata: Echinoidea) na Praia da Costa, Vila Velha, Espírito Santo. Zoologia (Curitiba), 26, 4, 641-646, DOI: https:// dx.doi.org/10.1590/S1984-46702009000400008.

NCCLS. National Committee for Clinical Laboratory Standards. 2003. Performance standards for antimicrobial disk suscepti- bility, $8^{\mathrm{a}}$ ed, 23, 1, NCCLS, West Valley Road, Pennsylvania, USA, pp. 1-58.

PAGANO, G., GUIDA, M., TRIFUOGGI, M., THOMAS, P., PALUMBO, A., ROMANO, G. \& ORAL, R. 2017. Sea urchin Bioassays in toxicity testing: I. Inorganics, organics, complex mixtures and natural products. Expert Opinion on Environmental Biology, 6, 1, DOI: https://dx.doi.org/10.4172/2325-9655.1000142.

PALMER, L. 1937. The shedding reaction in Arbacia punctulata. Physiological Zoology, 10, 352-367.

RIBEIRO M. B., FURLEY T., SPAGO F. R. \& PAREDES E. 2018a. First steps towards Echinometra lucunter embryo cryopreservation. Cryobiology, 80, 51-54.

RIBEIRO, R. C., VERONEZ, A. C. S., TOVAR, T. T., ADAMS, S., BARTOLOMEU, D. A., PERONICO, C. \& FURLEY T. H. 2018b. Cryopreservation: extending the viability of biological material from sea urchin (Echinometra lucunter) in ecotoxicity tests. Cryobiology, 80, 139-143.

RIBEIRO, A. O. J., VENTURA, C. R. R., CARVALHO, A. L. P. S. \& SCHMIDT, A. J. 1997. Population recovery of the sea urchin Lytechinus variegatus in a seagrass flat (Araruama Lagoon, Brazil): the role of recruitment in a disturbed environment. Invertebrate Reproduction and Development, 31, 1-3, 143-150.

SOARES, J. B. \& RESGALLA, C. JR. 2016. Echinodermata in ecotoxicological tests: maintenance and sensitivity. Brazilian Journal of Oceanography, 64, 1, 29-36, DOI: https://dx.doi. org/10.1590/S1679-87592016100106401.

SPIEGLER, M. A. \& OPPENHEIMER, S. B. 1995. Extending the viability of sea urchin gametes. Cryobiology, 32, 168-174.

USEPA. United States Environmental Protection Agency. 2002. EPA-821-R-02-014 - Short-term methods for estimating the chronic toxicity of effluents and receiving waters to marine and estuarine organisms. $3^{\text {rd }}$ ed. EPA, Washington, DC, pp. 1-486.

VACQUIER, V. D. 2011. Laboratory on Sea Urchin Fertilization. Molecular Reproduction \& Development, 78, 553-564.

VIEIRA NETO, O. M. \& MOYSÉS NETO, M. 2003. Distúrbios do equilíbrio hidroeletrolítico. Medicina, Ribeirão Preto, 36, 325-337.

ZAGATTO, P. A. 2006. Ecotoxicologia. In: ZAGATTO, P. A. \& BERTOLETTI, E. Ecotoxicologia aquática, princípios e aplicações. Editora Rima, São Paulo, pp. 1-13. 